\section{KREATIF}

Jurnal Ilmiah

Prodi Manaiemen Universitas Pamulang
Pamulang ISSN : $2339-0689$, E-ISSN : 2406-8616

J. KREATIF, Vol. 7, No. 2, Desember 2019 (Halaman 26-42)

Tersedia Online di : http://openjournal.unpam.ac.id/index.php/kreatif

\title{
PENGARUH EARNING PER SHARE DAN BOOK VALUE PER SHARE TERHADAP HARGA SAHAM PT LIPPO KARAWACI, TBK.
}

\author{
Tri Wartono', Evina ${ }^{2}$ \\ Program Studi Manajemen \\ ${ }^{1}$ Dosen Universitas Pamulang \\ ${ }^{2}$ Mahasiswa Universitas Pamulang \\ wartono04@yahoo.com
}

\begin{abstract}
ABSTRAK
Tujuan dari penelitian ini adalah untuk mengetahui pengaruh Earning Per Share (EPS) dan Book Value Per Share (BVPS) terhadap fluktuasi harga saham pada PT Lippo Karawaci, Tbk dalam kurun waktu 12 (duabelas) tahun terakhir dari tahun 2005 sampai 2016.

Metode penelitian kuantitatif dengan menggunakan data laporan keuangan (time-series) selama 12 (duabelas) tahun 2005 sampai dengan 2016. Penelitian ini menggunakan data sekunder yang bersumber dari laporan tahunan yang telah terpublikasi. Analisis statistik, meliputi uji asumsi klasik, persamaan regresi berganda, koefisien korelasi dan determinasi serta pengujian hipotesis/uji-signifikansi.

Hasil pengujian bahwa variabel Earning Per Share (EPS) secara parsial berpengaruh signifikan terhadap variabel harga saham $(0,021<0,050)$, dan variabel Book Value Per Share (BVPS) secara parsial berpengaruh tidak signifikan terhadap variabel harga saham $(0,333>0,05)$. Sementara bahwa EPS dan BVPS secara bersama-sama (simultan) berpengaruh signifikan, karena nilai sig. lebih kecil dari $0,05(0,006<0,050)$.
\end{abstract}

Kata Kunci : $E P S, B V P S$ dan harga saham

\section{ABSTRACT}

The purpose of this study was to determine the effect of Earning Per Share (EPS) and Book Value Per Share (BVPS) on fluctuations in share prices at PT Lippo Karawaci, Tbk within the last 12 (twelve) years from 2005 to 2016.

Quantitative research methods using financial statement data (timeseries) for 12 (twelve) from 2005 to 2016. This study uses secondary data sourced from published annual reports. Statistical analysis, including the classical assumption test, multiple regression equations, correlation coefficients and determination as well as testing hypotheses / significancetests.

The test results show that the Earning Per Share (EPS) variable partially has a significant effect on the stock price variable $(0.021<0.050)$, and the Book Value Per Share (BVPS) variable has a partially insignificant effect on the stock price variable (0.333>0.05). Meanwhile, EPS and BVPS together (simultaneously) have a significant effect, because the sig value. smaller than $0.05(0.006<0.050)$.

Keywords: EPS, BVPS and stock prices 


\section{PENDAHULUAN}

\section{A. Latar Belakang Masalah}

Bursa saham merupakan sarana efektif untuk mempercepat pembangunan peekonomian suatu negara. Dan juga merupakan wadah alternatif selain bank dan lembaga keuangan non bank bagi para investor untuk mealokasikan portofilio investasiau investasi. Salah satu indikasi bekerjanya pasar modal secara optimal adalah ketersediaan dan keterbukan informasi, baik bidang keuangan maupun non keuangan yang bersifat simetris dan dapat diperoleh oleh semua pihak yang berkepentingan. Interaksi antara emiten sebagai penerbit sekurias dan investor sebagai pembeli akan menentukan volume pergerakan dana masyarakat. Kinerja keuangan perusahaan merupakan salah satu aspek yang dinilai oleh invertor dapat diketahui dari hasil analisis laporan keuangan perusahaan yang selalu dipublikasikan secara periodik. Dengan kata lain, sebuah laporan keuangan dapat dijadikan bahan pertimbangan bagi para calon investor saat akan melakukan pilihan investasi. Bursa Efek Indnesia (BEI) yang tumbuh pesat sepuluh tahun terakhir sungguh sangat menarik bagi para investor lokal maupun investor asing, sejalan dengan kesadaran masyarakat akan peranan pasar modal dalam penyediaan dana untk pengembangan bisnis dan pembangunan. Hal ini dapat dilihat dari peningkatan jumlah perusahaan yang go public, dan nilai kapitalisasi yang semakin tinggi serta volume perdagangan yang semakin tinggi dari aktivitas perdagangan di bursa. Saham berkinerja buruk adalah saham suatu perusahaan yang tidak dapat menghasilkan laba atau rugi terusmenerus. Kondisi seperti ini tentu akan berpengaruh terhadap pergerakan harga sahamnya.

PT Lippo Karawaci, Tbk, sebagai obyek penelitian karena bidang usaha Property dan Real Estat) dipandang sebagai sektor yang penting dan terus berkembang sejalan dengan pertumbuhan penduduk yang terus bertambah. Pertumbuhan jumlah penduduk akan mendorong peningkatkan kebutuhan sektor ini. Sejak tahun 2016 dan tahun-tahun ke depan diprediksi akan terus berkembang, dengan telah diterbitkan paket kebijakan pemerintah untuk meningkatkan pertumbuhan ekonomi khususnya di sektor property. Earning Per Share (EPS) adalah salah satu indikator keberhasilan manajemen untuk mencapai tujuan bagi pemegang saham yaitu tingkat keuntungan. PT Lippo Karawaci, Tbk dalam laporan keungan secara periodik juga menggunakan EPS sebagai tolok ukur peningkatan kinerja perusahaan.

Hal lain yang juga akan diperhatikan oleh para investor adalah Book Value Per Share (BVPS). EPS dan BVPS digunakan sebagai alat ukur kemampuan perusahaan dan sekaligus sebagai acuan oleh investor untuk menganalisis, sehingga mempengaruhi penilaian investor (Tryfino, 2009:9). Oleh karena itu, penting kiranya bagi PT Lippo Karawaci, Tbk memperhatikan kedua hal tersebut sebagai indikator yang berperan penting...

Perkembangan nilai saham PT Lippo Karawaci, Tbk diduga juga dipengaruhi oleh variabel EPS dan BVPS yang selalu mengalami fluktuasi. Pada periode tertentu, saat terjadi kenaikan $B V P S$ di sertai 
kenaikan harga saham, demikian pula kenaikan EPS juga diikuti dengan kenaikan harga saham. Dengan demikian dapat diduga bahwa kedua variabel tersebut mempunyai pengaruh positif dan sejalan dengan peubahan harga saham. Namun pada kenyataan pergerakan pada periode penilaian selama duabelas tahun terakhir tidaklah selalu demikian. Bahkan beberapa kali terjadi sebaliknya diana saat EPS dan BVPS naik tetapi harga saham turun

Berikut disajikan perkembangan BVPS dan EPS dan harga saham yang disajikan dalam satuan rupiah penuh.

Tabel

Perkembangan EPS, BVPS, dan Harga Saham

PT Lippo Karawaci, Tbk

(dalam satuan rupiah penuh)

\begin{tabular}{|c|r|r|r|}
\hline Periode & \multicolumn{1}{|c|}{$\boldsymbol{E P S}$} & $\boldsymbol{B} \boldsymbol{V P S}$ & Harga Saham \\
\hline 2005 & 124,02 & 930,35 & 1.664 \\
\hline 2006 & 55,18 & 503,26 & 1.017 \\
\hline 2007 & 23,51 & 280,11 & 656 \\
\hline 2008 & 21,44 & 260,11 & 761 \\
\hline 2009 & 22,43 & 305,68 & 485 \\
\hline 2010 & 30,30 & 471,77 & 680 \\
\hline 2011 & 31,56 & 419,19 & 660 \\
\hline 2012 & 46,48 & 502,81 & 1.000 \\
\hline 2013 & 53,94 & 622,60 & 910 \\
\hline 2014 & 112,26 & 773,81 & 1.020 \\
\hline 2015 & 23,51 & 830,72 & 1.035 \\
\hline 2016 & 38,75 & 969,42 & 720 \\
\hline \multicolumn{3}{|c|}{ Sumber : Survey Awal 2017} &
\end{tabular}

Berdasarkan data dan anomali hubungan dan pengaruh variabelvariabel tersebut yang mendorong untuk melakukan penelitian lebih mendalam guna mengetahui lebih lanjut atas fenomena dan pengaruh serta hubungan antar variabel dengan judul yag tertera di atas.

\section{B. Rumusan Masalah}

Saham PT Lippo Karawaci, Tbk menunjukkan kondisi yang fluktuatif dan menurun di akhir tahun 2016 sebagai permasalahan pokok. Berdasarkan research problem tersebut maka dapat disusun pertanyaan penelitian atau research question sebagai berikut :

1. Bagaimana pengaruh perkembangan nilai EPS secara individu terhadap perubahan saham PT Lippo Karawaci, Tbk?

2. Bagaimana pengaruh pekembangan nilai BVPS secara parsial terhadap perubahan harga saham PT Lippo Karawaci, Tbk?

3. Bagaimana pengaruh perkembangan EPS dan BVPS secara simultan terhadap perubahan saham PT Lippo Karawaci, Tbk?

\section{KERANGKA BERFIKIR}

Perkembangan harga saham sebagai variabel terikat, tidak akan terlepas dari pekembangan kinerja keuangan perusahaan yang bisa dilihat dari nilai BVPS dan EPS sebagai vaiabel bebas. Kedua variabel tersebut secara individu akan bisa berpengaruh terhadap variabel tergantung dan 
sekaligus secara simultan juga berpengaruh terhadap variabel tujuan. Besarnya pengaruh postif atau negatif serta signifikan atau tidak signifannya pengaruh tersebut dapat dilakukan dngan uji-hipotesis pada penelitian ini. Analisis fundamental mempelajari laporan keuangan termasuk rasio perusahaan yang berlandaskan bahwa perubahan harga saham dipengaruhi oleh kinerja keuangan. Sedangkan analisis teknikal adalah pelengkap analisis fundamental

\section{A. Pengaruh EPS terhadap harga saham}

EPS merupakan jumlah laba atau keuntungan yang diperoleh dalam satu periode untuk tiap lembar saham. EPS juga merupakan gambaran mengenai kemampuan perusahaan dalam menghasilkan keuntungan bersih setiap lembar saham. Semakin tinggi nilai EPS berarti semakin baik. Signifikan tidaknya pengaruh variabel bebas terhadap variabel tujuan inilah yang menjadi kajian dalam penelitian ini.

\section{B. Pengaruh BVPS terhadap harga saham}

Book Value Per Share pada dasarnya adaah nilai aset/ekuitas yang dimiliki perusahaan tersebut. Secara normal, BVPS akan terus naik seiring dengan kinerja perusahaan yang membaik, demikian pula sebaliknya. Niai aset yang cenderung meningkat akan meningkatkan pula nilai BVPS, juga akan mendorong terhadap prubahan harga saham. Bila nilai BVPS meningkat diduga harga saham juga meningkat dan sebaliknya. Hal ini mengindikasikan adanya pengaruh positif diantara dua varibel dimaksud.

\section{Pengaruh BVPS dan EPS scara simultan}

Emiten yang meghasilkan EPS tinggi menunjukkan bahwa tingkat efisiensi dan efektivitas pengelolaan pendaatan perusahaan yang tinggi. Hal ini menunjukkan kondisi dan kinerja perusahaan yang baik. Investor akan lebih tertarik untuk menginvestasikan dananya kepada perusahaan yang memiliki prospek yang cerah. Oleh karena itu, EPS yang tinggi dapat memberikan suatu sinyal baik bagi pasar, sehingga respon positif yang ditunjukkan oleh pasar akan meningkatkan harga saham. Sebaliknya perusahaan dengan hasil EPS rendah berarti perusahaan berkinerja rendah dengan revnue yang rendah pula. Pendapatan yang rendah karena penjualan tidak maksimal atau berbiaya tinggi. BVPS yang tinggi pada umumnya akan disertai dengan harga saham yang tinggi, demikian sebaliknya jika $B V P S$ rendah maka harga saham ikut rendah. Diagram kerangka pemikiran sebagai berikut:

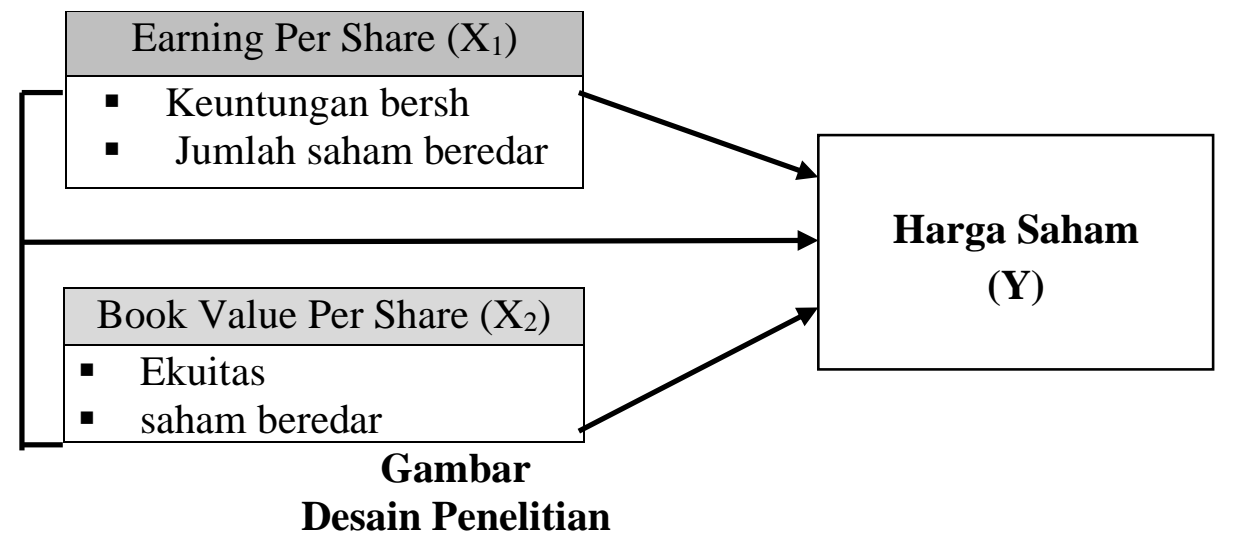




\section{Hipotesis Penelitian}

$\mathrm{H}_{1}$ : Diduga terdapat pengaruh positif dan signifikan variabel $B V P S$ secara parsial terhadap harga saham PT Lippo Karawaci, Tbk.

$\mathrm{H}_{2}$ : Diduga terdapat pengaruh positif dan signifikan variabel EPS scara parsial terhadap harga saham PT.Lippo Karawaci, Tbk.

$\mathrm{H}_{3}$ : Diduga terdapat pengaruh positif dan signifikan variabel $B V P S$ dan EPS secara bersama-sama terhadap harga saham PT Lippo Karawaci, Tbk.

\section{METODE PENELITIAN}

\section{A. Ruang Lingkup Penelitian}

Penelitian ini bersifat inferensial kuantitatif..Menurut Sugiyono (2014:41) objek penelitian adalah sasaran ilmiah untuk mendapatkan data dengan tujuan dan kegunaan tertentu tentang suatu hal objektif, valid dan reliable dari suatu hal atau variabel tertentu. Dalam penelitian ini yang menjadi objek penelitian adalah laporan keuangan PT Lippo Karawaci, Tbk khususnya laporan laba/rugi dan necara tyang telah diaudit dan dipublikasikan di dalam website resmi www.lippokarawaci.co.id.

Variabel independen adalah Earning Per Share (EPS) dan Book Value Per Share (BVPS), sedangkan variabel dependennya adalah harga saham yang semuanya duidapat dari PT Lippo Karawaci, Tbk.

\section{B. Metode Pengumpulan Data}

Penelitian menggunakan data sekunder yaitu Laporan Tahunan (annual report) PT Lippo Karawaci, Tbk yang telah dipubikasikan di BEI yang terdiri dari : (1) Laporan Keuangan PT Lippo Karawaci, Tbk tahun 2012-2017; (2) Harga saham yang diambil dari tutup pasar di akhir tahun dan berbagai jenis laporan keuangan lainnya selama 12 tahun terakhir.

\section{Teknik Pengumpulan Data}

\section{Penelitian Dokumentasi (Documentation Research)}

Menggunakan dan mengandalkan dokumen sebagai basis penelitian (documentary research). Teknik pengumpulan data dilakukan dengan menyelidiki benda-benda tertulis seperti laporan keuangan PT Lippo Karawaci, Tbk dan catatan harga saham serta dokumen-dokumen lainnya yang relevan.

\section{Penelitian Kepustakaan (Library Research)}

Mengumpulkan data yang bersumber dari perpustakaan baik yang berupa buku, literatur, serta dokumen dan materi lainnya yang berkaitan erat dengan permasalahan penelitian ini.

\section{Penelitian Internet (Internet Research)}

Penelitian ini dilakukan dengan cara searching dan download sumber-sumber data yang berhubungan dengan variabel-variabel penelitian dan yang berkaitan dengan topik masalah.

\section{Metode Analisis}

\section{Analisis Rasio}

Analisis variabel bebas dilakukan dengan menghitung nilai ratio untuk 12 tahun, dan melihat kecenderungannya dan 
menyimpulkan apakah semakin membaik atau sebaliknya. Dua variabel ini dapat digunakan untuk memprediksi kecenderungan arah perubahan harga sebelum menentukan pilihan investasi. Data EPS dan BVPS diperoleh dari hasil analisis laporan keuangan PT Lippo Karawaci, Tbk pada periode 2005-2016.

2. Analisis Statistik Inferensial

Analisisi Statistikdengan menggunakan aplikasi IBM SPSS

Statistic 20 for Windows. Yaitu meliputi :
a. Uji Asumsi Klasik terdiri: (1) Uji Normalitas; (2) Uji Multikolinieritas; (3) Uji Heteroskedastisitas; (4) Uji Autokorelasi
b. Regresi Berganda
c. Analisis Koefisien Korelasi
d. Koefisien Determinasi
e. Uji Hipotesis : (1) Uji t (Partial), (2) Uji F (Simultan )

\section{ANALISIS DAN PEMBAHASAN}

\section{A. Basis Data Penelitian}

\section{Tabel}

Data Inti PT Lippo Karawaci, Tbk. Periode 2005-2016

(dalam satuan rupiah)

\begin{tabular}{|c|c|c|c|c|r|}
\hline \multirow{2}{*}{ No } & \multirow{2}{*}{ Tahun } & Laba Rugi & Neraca & \multirow{2}{*}{$\begin{array}{c}\text { Jumlah Saham } \\
\text { Beredar }\end{array}$} & $\begin{array}{c}\text { Harga } \\
\text { Saham }\end{array}$ \\
\cline { 3 - 4 } & & Laba Bersih & Jumlah Ekuitas & \multicolumn{1}{c|}{ Sam } \\
\hline 1 & 2005 & 358.943 .471 .241 & 2.692 .634 .412 .966 & 2.894 .210 .124 & 1.664 \\
\hline 2 & 2006 & 324.836 .371 .332 & 2.962 .488 .557 .445 & 5.886 .538 .879 & 1.017 \\
\hline 3 & 2007 & 353.027 .466 .695 & 4.206 .059 .914 .698 & 15.015 .963 .393 & 656 \\
\hline 4 & 2008 & 370.872 .333 .757 & 4.500 .494 .272 .136 & 17.302 .151 .695 & 761 \\
\hline 5 & 2009 & 388.053 .495 .627 & 5.288 .931 .594 .918 & 17.302 .151 .695 & 485 \\
\hline 6 & 2010 & 525.345 .786 .018 & 8.179 .417 .320 .938 & 17.337 .704 .061 & 680 \\
\hline 7 & 2011 & 708.282 .328 .610 & 9.409 .018 .194 .454 & 22.445 .796 .783 & 660 \\
\hline 8 & 2012 & 1.060 .221 .934 .429 & 11.470 .106 .390 .475 & 22.812 .143 .338 & 1.000 \\
\hline 9 & 2013 & 1.228 .230 .222 .876 & 14.177 .573 .305 .225 & 22.771 .585 .119 & 910 \\
\hline 10 & 2014 & 2.556 .247 .574 .832 & 17.620 .829 .858 .097 & 22.771 .585 .119 & 1.020 \\
\hline 11 & 2015 & 535.394 .000 .000 & 18.916 .764 .000 .000 & 22.771 .585 .119 & 1.035 \\
\hline 12 & 2016 & 882.441 .000 .000 & 22.075 .139 .000 .000 & 22.771 .585 .119 & 720 \\
\hline
\end{tabular}

Sumber : Laporan Keuangan PT Lippo Karawaci, Tbk Tahun 2012-2016, www.duniainvestasi.com

\section{B. Pembahasan}

\section{Perhitungan dan Analisis Variabel EPS}

Tabel

Perhitungan EPS PT Lippo Karawaci, Tbk

(dalam rupiah penuh)

\begin{tabular}{|r|c|r|r|r|r|}
\hline No & Tahun & \multicolumn{1}{c|}{$\begin{array}{c}\text { Laba/Rugi } \\
\text { Laba Bersih (1) }\end{array}$} & $\begin{array}{c}\text { Jumlah Saham } \\
\text { Beredar (2) }\end{array}$ & $\begin{array}{c}\text { EPS } \\
(3)=(1: 2)\end{array}$ & $\begin{array}{c}\text { Selisih }(\Delta) \\
(+/-)\end{array}$ \\
\hline 1 & 2005 & 358.943 .471 .241 & 2.894 .210 .124 & 124,02 & - \\
\hline 2 & 2006 & 324.836 .371 .332 & 5.886 .538 .879 & 55,18 & $-68,84$ \\
\hline 3 & 2007 & 353.027 .466 .695 & 15.015 .963 .393 & 23,51 & $-31,67$ \\
\hline 4 & 2008 & 370.872 .333 .757 & 17.302 .151 .695 & 21,44 & $-2,07$ \\
\hline 5 & 2009 & 388.053 .495 .627 & 17.302 .151 .695 & 22,43 & 0,99 \\
\hline
\end{tabular}




\begin{tabular}{|r|r|r|r|r|r|}
\hline 6 & 2010 & 525.345 .786 .018 & 17.337 .704 .061 & 30,30 & 7,87 \\
\hline 7 & 2011 & 708.282 .328 .610 & 22.445 .796 .783 & 31,56 & 1,26 \\
\hline 8 & 2012 & 1.060 .221 .934 .429 & 22.812 .143 .338 & 46,48 & 14,92 \\
\hline 9 & 2013 & 1.228 .230 .222 .876 & 22.771 .585 .119 & 53,94 & 7,46 \\
\hline 10 & 2014 & 2.556 .247 .574 .832 & 22.771 .585 .119 & 112,26 & 58,32 \\
\hline 11 & 2015 & 535.394 .000 .000 & 22.771 .585 .119 & 23,51 & $-88,75$ \\
\hline 12 & 2016 & 882.441 .000 .000 & 22.771 .585 .119 & 38,75 & 15,24 \\
\hline \multicolumn{5}{|c|}{ Rata-rata Delta $(\Delta)$} & $-7,75$ \\
\hline
\end{tabular}

Sumber : Laporan Keuangan PT Lippo Karawaci, Tbk. (data diolah)

Untuk memudahkan dalam membaca mengenai Earing Per Share

(EPS) PT Lippo Karawaci, Tbk, nilai tabel di atas dapat dlihat dalam grafik berikut:

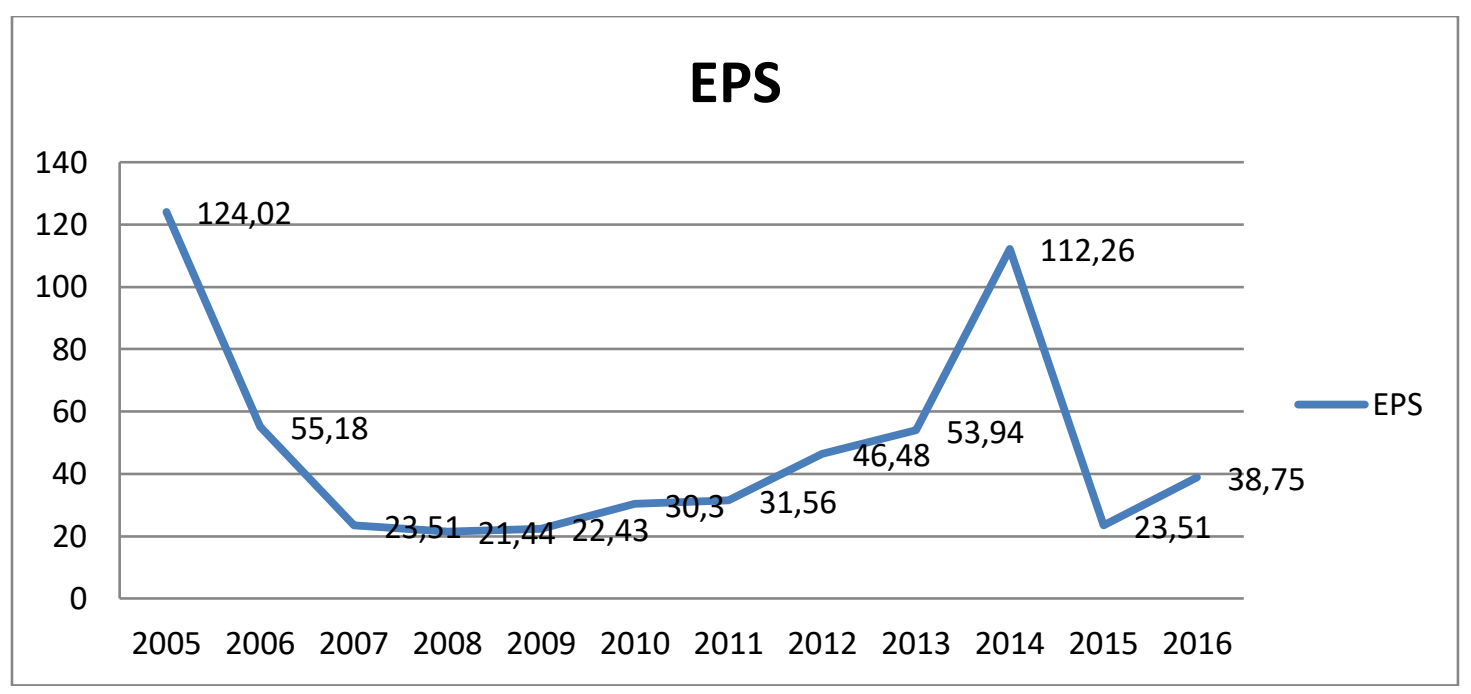

\section{Gambar \\ Grafik Perubahan nilai EPS}

\section{Perhitungan dan Analisis Variabel BVPS}

\section{Tabel}

Hasil Perhitungan BVPS PT. Lippo Karawaco,Tbk

(dalam satuan rupiah penuh)

\begin{tabular}{|c|c|c|c|r|r|}
\hline \multirow{2}{*}{ No } & \multirow{2}{*}{ Tahun } & Neraca & Jumlah Saham & \multicolumn{1}{c|}{ BVPS } \\
\cline { 3 - 4 } & & Jumlah Ekuitas $(1)$ & \multicolumn{1}{c|}{$\begin{array}{c}\text { Belta }(\Delta) \\
(+/-)\end{array}$} \\
\hline 1 & 2005 & 2.692 .634 .412 .966 & 2.894 .210 .124 & 930,35 & - \\
\hline 2 & 2006 & 2.962 .488 .557 .445 & 5.886 .538 .879 & 503,26 & $-427,09$ \\
\hline 3 & 2007 & 4.206 .059 .914 .698 & 15.015 .963 .393 & 280,11 & $-223,15$ \\
\hline 4 & 2008 & 4.500 .494 .272 .136 & 17.302 .151 .695 & 260,11 & -20 \\
\hline 5 & 2009 & 5.288 .931 .594 .918 & 17.302 .151 .695 & 305,68 & 45,57 \\
\hline 6 & 2010 & 8.179 .417 .320 .938 & 17.337 .704 .061 & 471,77 & 166,09 \\
\hline 7 & 2011 & 9.409 .018 .194 .454 & 22.445 .796 .783 & 419,19 & $-58,58$ \\
\hline 8 & 2012 & 11.470 .106 .390 .475 & 22.812 .143 .338 & 502,81 & 83,62 \\
\hline 9 & 2013 & 14.177 .573 .305 .225 & 22.771 .585 .119 & 622,60 & 119,79 \\
\hline 10 & 2014 & 17.620 .829 .858 .097 & 22.771 .585 .119 & 773,81 & 151,21 \\
\hline 11 & 2015 & 18.916 .764 .000 .000 & 22.771 .585 .119 & 830,72 & 56,91 \\
\hline 12 & 2016 & 22.075 .139 .000 .000 & 22.771 .585 .119 & 969,42 & 138,7 \\
\hline
\end{tabular}




\section{Rata-rata Delta $(\Delta)$}

\section{3,5518}

Sumber : Laporan Keuangan PT Lippo Karawaci, Tbk. (data diolah)

Untuk memudahkan dalam membaca mengenai Book Value Per

Share (BVPS) PT Lippo Karawaci, Tbk, nilai tabel di atas dapat dilihat pada grafik berikut :

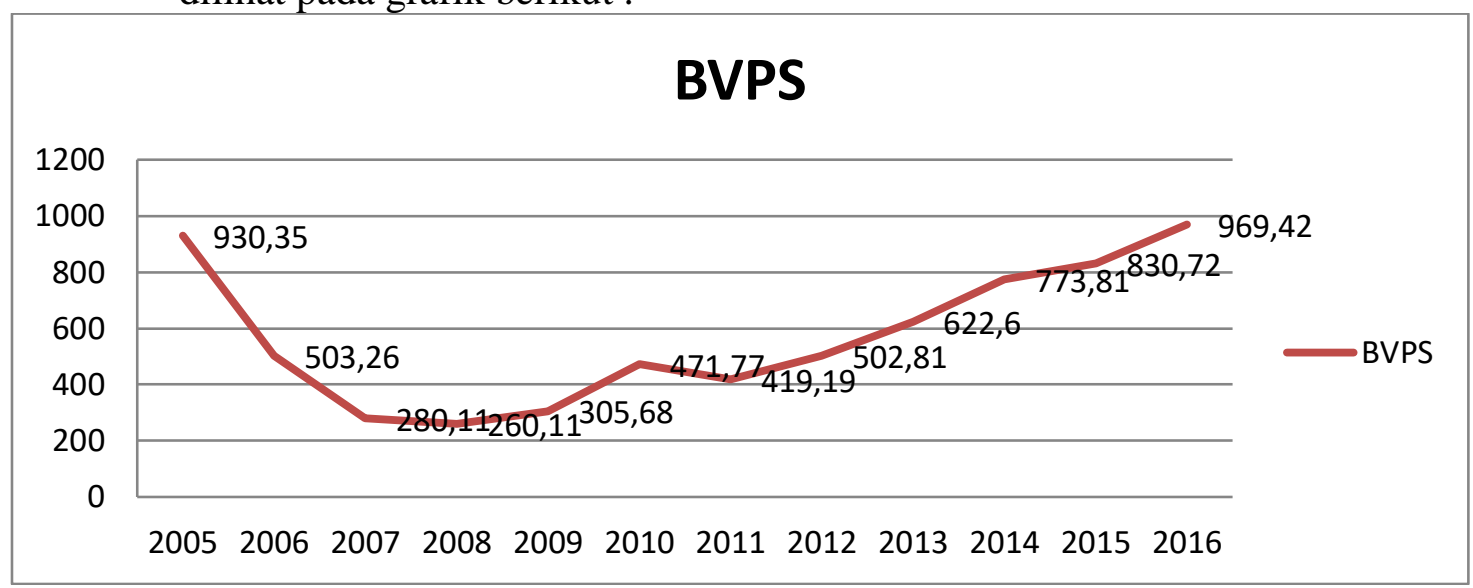

\section{Gambar}

\section{Grafik Perkembangan BVPS}

\section{Harga Saham}

Perkembangan harga saham selama duabelas tahun terakhir yang termonitor pada pasar bursa seperti berikut.

Tabel

Data Harga Saham PT Lippo Karawaci,Tbk

\begin{tabular}{|c|c|r|r|}
\hline No & Tahun & $\begin{array}{c}\text { Harga } \\
\text { Saham }\end{array}$ & \multicolumn{1}{c|}{$\begin{array}{c}\text { Delta } \\
(\Delta)\end{array}$} \\
\hline 1 & 2005 & 1.664 & - \\
\hline 2 & 2006 & 1.017 & -647 \\
\hline 3 & 2007 & 656 & -361 \\
\hline 4 & 2008 & 761 & 105 \\
\hline 5 & 2009 & 485 & -276 \\
\hline 6 & 2010 & 680 & 195 \\
\hline 7 & 2011 & 660 & -20 \\
\hline 8 & 2012 & 1.000 & 340 \\
\hline 9 & 2013 & 910 & -90 \\
\hline 10 & 2014 & 1.020 & 110 \\
\hline 11 & 2015 & 1.035 & 15 \\
\hline 12 & 2016 & 720 & -315 \\
\hline \multicolumn{3}{|c|}{ Rata-rata Delta $(\Delta)$} & $-85,8182$ \\
\hline
\end{tabular}

Sumber : www.duniainvestasi.com

Nilai tabel di atas dapat lebih jelas dengan menggunakan grafik berikut 


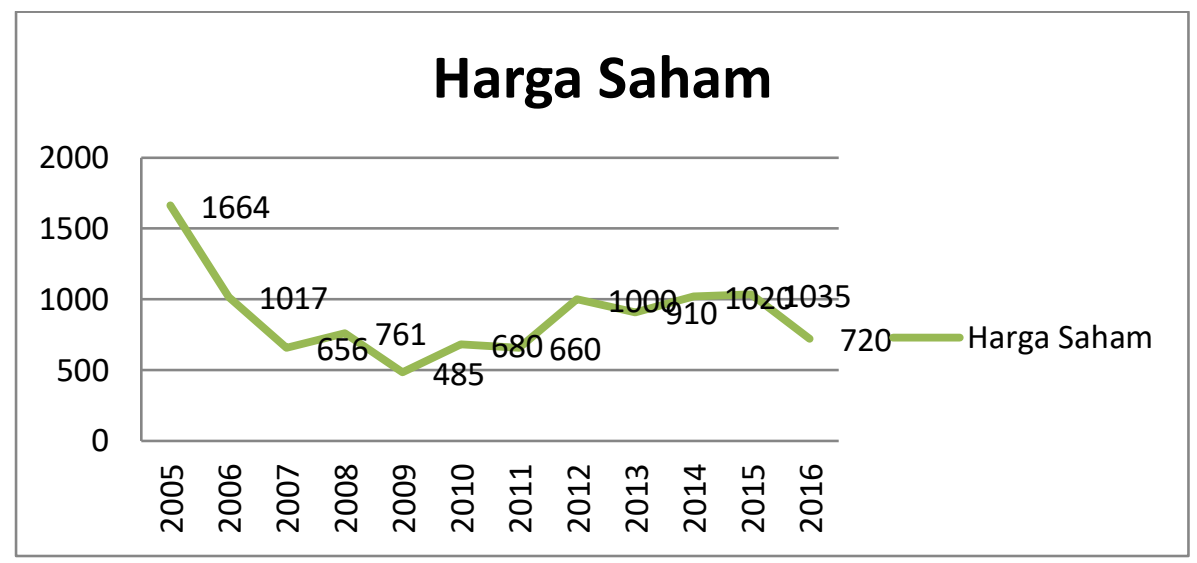

Gambar 4.4

Grafik Perkembangan Harga Saham

\section{Hasil Pehitungan Variabel Penelitian}

Tabel

Input Pengolahan Data Aplikasi SPSS 20

(dalam satuan rupiah)

\begin{tabular}{|c|c|r|r|r|}
\hline No & Tahun & \multicolumn{1}{c|}{ EPS } & \multicolumn{1}{c|}{ BVPS } & Harga Saham \\
\hline 1 & 2005 & 124,02 & 930,35 & 1.664 \\
\hline 2 & 2006 & 55,18 & 503,26 & 1.017 \\
\hline 3 & 2007 & 23,51 & 280,11 & 656 \\
\hline 4 & 2008 & 21,44 & 260,11 & 761 \\
\hline 5 & 2009 & 22,43 & 305,68 & 485 \\
\hline 6 & 2010 & 30,30 & 471,77 & 680 \\
\hline 7 & 2011 & 31,56 & 419,19 & 660 \\
\hline 8 & 2012 & 46,48 & 502,81 & 1.000 \\
\hline 9 & 2013 & 53,94 & 622,60 & 910 \\
\hline 10 & 2014 & 112,26 & 773,81 & 1.020 \\
\hline 11 & 2015 & 23,51 & 830,72 & 1.035 \\
\hline 12 & 2016 & 38,75 & 969,42 & 720 \\
\hline
\end{tabular}

Sumber : Laporan Keuangan PT Lippo Karawaci, Tbk. (data diolah)

1. Analisis Statistik dengan IBM SPSS Statistic 20 for Window

a.) Uji Asumsi Klasik

1.) Normalitas

Tabel

Hasil Uji Normalitas

One-Sample Kolmogorov-Smirnov Test

\begin{tabular}{|lc|r|}
\hline & \multicolumn{2}{|c|}{$\begin{array}{c}\text { Unstandardized } \\
\text { Residual }\end{array}$} \\
\hline N & 12 \\
Normal Parameters & Mean & $0 \mathrm{E}-7$
\end{tabular}




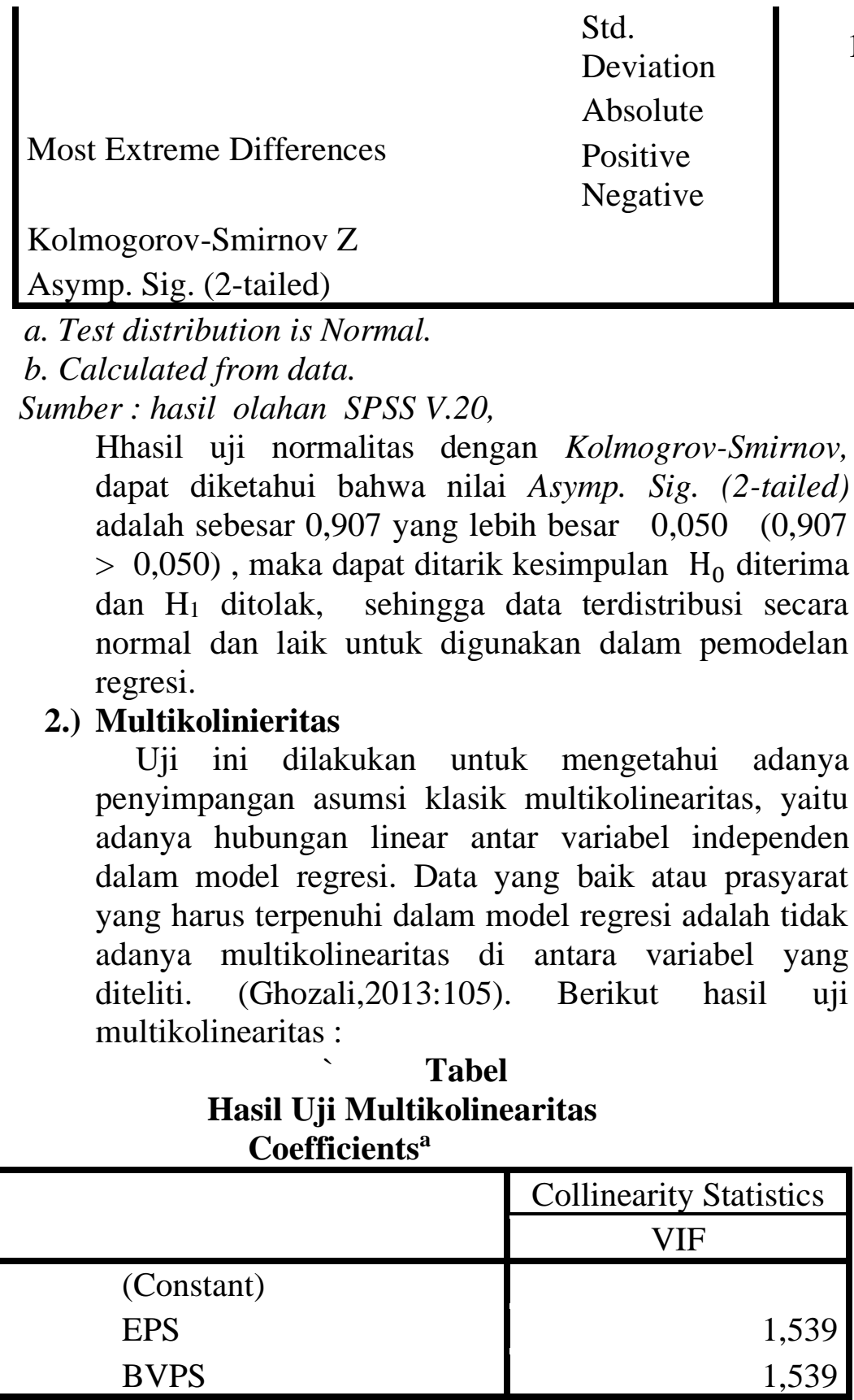

a. Dependent Variable: HS

Sumber : SPSS V.20,

Berdasarkan tabel 4.7 di atas, dapat dipastikan bahwa pada variabel EPS dan BVPS menunjukkan angka VIF (Variance Inflation Factor) sebesar 1,539 masih dibawah/lebih kecil dari 10. Maka bisa dinyatakan bahwa model regresi berganda tidak terdapat masalah multikolinearitas.

3.) Heteroskedastisitas

Model regresi yang baik adalah yang homoskesdastisitas atau tidak terjadi heteroskesdastisitas. Cara untuk mendeteksi ada atau tidaknya heteroskesdastisitas, antara lain dengan melihat grafik plot antara nilai prediksi variabel terikat 
(dependen) yaitu ZPRED dengan residual SRESID. Berikut ini grafik scatterplot dari model regresi penelitian ini :

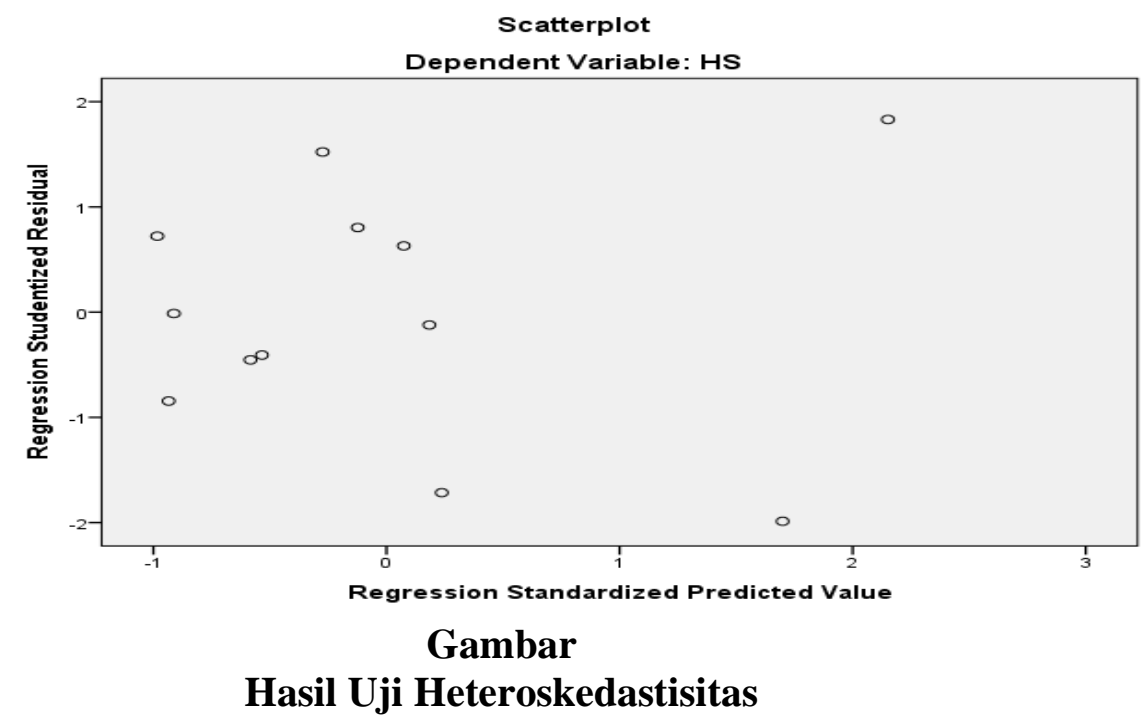

Dari gambar 4.5 hasil uji heteroskedastisitas, dapat dicermati bahwa titik-titik menyebar secara acak, dan tidak membentuk pola tertentu, serta tersebar baik di atas maupun di bawah angka 0 pada sumbu Y. Maka dapat diambil kesimpulan bahwa pada model regresi tidak terdapat gejala heteroskedastisitas.

\section{4.) Autokorelasi}

Uji autokorelasi digunakan untuk memastikan apakah dalam model regresi linear terdapat korelasi antara kesalahan pengganggu pada periode $t$ dengan kesalahan pengganggu pada periode t-1 (sebelumnya). Model regresi yang baik adalah regresi yang bebas dari autokorelasi. (Ghozali, 2013:111) Untuk mendeteksi ada tidaknya autokorelasi dilakukan dengan menggunakan metode uji Durbin-Watson (DW test). Berikut hasilnya :

\section{Tabel}

Hasil Uji Autokorelasi

Model Summary ${ }^{\mathrm{b}}$

\begin{tabular}{|l|r|r|r|c|c|}
\hline Model & $\mathrm{R}$ & R Square & $\begin{array}{c}\text { Adjusted R } \\
\text { Square }\end{array}$ & $\begin{array}{c}\text { Std. Error of the } \\
\text { Estimate }\end{array}$ & $\begin{array}{c}\text { Durbin- } \\
\text { Watson }\end{array}$ \\
\hline 1 &, $823^{\mathrm{a}}$ &, 677 &, 605 & 192,00803 & 2,274 \\
\hline
\end{tabular}

a. Predictors: (Constant), BVPS, EPS

b. Dependent Variable: HS

Sumber : Data Sekunder diolah SPSS V.20, 2018

Berdasarkan tabel di atas, dapat diketahui nilai DW sebesar 2,274. Secara teori yang dinyatakan oleh Ghozali, dinyatakan bahwa nilai DW yang tidak ada autokorelasi positif atau negatif jika dU $<\mathrm{d}<4$-dU, nilai dU sebesar 1,5794 dan nilai 4-dU sebesar 2,4206. 
Letak DW antara $1,5794<2,274<2,4206$. dapat disimpulkan bahwa model persamaan tersebut tidak terdapat autokorelasi, sehingga uji regresi ini layak untuk dilanjutkan.

\section{Regresi Linier Berganda}

Analisis ini digunakan untuk mengetahui arah hubungan antara variabel independen dengan variabel dependen apakah masing-masing variabel independen berpengaruh positif atau negatif dalam memprediksi nilai dari variabel dependen apabila nilai variabel independen mengalami perubahan. Dengan menggunakan model regresi linier berganda dilakukan untuk mengetahui seberapa besar pengaruh variabel independen yaitu earning per share dan book value per share terhadap variabel dependen yaitu harga saham PT Lippo Karawaci, Tbk.

\section{Tabel}

Hasil Uji Regresi Linier Berganda

Coefficients $^{\text {a }}$

\begin{tabular}{|l|l|r|r|r|}
\hline \multicolumn{2}{|l|}{ Model } & \multicolumn{2}{|c|}{ Unstandardized Coefficients } & \multicolumn{1}{c|}{$\begin{array}{c}\text { Standardized } \\
\text { Coefficients }\end{array}$} \\
\cline { 3 - 5 } \multicolumn{2}{|c|}{} & \multicolumn{1}{|c|}{ B } & \multicolumn{1}{c|}{ Std. Error } & \multicolumn{2}{c|}{ Beta } \\
\hline \multirow{3}{*}{1} & (Constant) & 434,871 & 143,265 & \\
& EPS & 5,790 & 2,072 &, 657 \\
& BVPS &, 293 &, 286 &, 241 \\
\hline
\end{tabular}

a. Dependent Variable: HS

Sumber : Data diolah SPSS V.20, 2018

Hasil pengujian diperoleh regresi sebagai berikut :

$Y=434,871+5,790 X_{1}+\mathbf{0 , 2 9 3} X_{2}$. yang dapat dijelaskant :

a. Konstanta (a)

Nilai konstanta bertanda positif 434,871 yang menunjukkan apabila variabel EPS dan BVPS bernilai 0 (nol), maka harga saham (Y) sebesar Rp. 434,871.

\section{b. EPS $\left(X_{1}\right)$ terhadap harga saham (Y)}

Nilai koefisien EPS untuk variabel $\mathrm{X}_{1}$ sebesar 5,790 dan bertanda positif. Hal ini menunjukkan bahwa setiap kenaikan EPS sebesar Rp 1, maka harga saham akan naik sebesar Rp.5,790 dengan asumsi bahwa variabel bebas yang lain dari model regresi adalah tetap.

c. BVPS $\left(\mathrm{X}_{2}\right)$ terhadap harga saham $(\mathrm{Y})$

Nilai koefisien BVPS untuk variabel $\mathrm{X}_{2}$ sebesar 0,293 dan bertanda positif. Hal ini menunjukkan bahwa setiap kenaikan BVPS sebesar Rp 1, maka harga saham akan naik sebesar Rp. 0,293 dengan asumsi bahwa variabel bebas yang lain dari model regresi adalah tetap.

\section{Koefisien Korelasi}

Analisis korelasi dengan menggunakan uji koefisien korelasi dimaksudkan untuk mengukur tingkat kekuatan hubungan antara variabel bebas dan variabel tujuan.(Sugiyono;2013:228). 
Tabel

Uji Koefisien Korelasi

Correlations

\begin{tabular}{|l|l|r|r|r|}
\hline \multicolumn{2}{|c|}{} & \multicolumn{1}{|c|}{ EPS } & \multicolumn{1}{c|}{ BVPS } & \multicolumn{1}{c|}{ HS } \\
\hline \multirow{4}{*}{ EPS } & Pearson Correlation & 1 &, $592^{*}$ &, $799^{* *}$ \\
\cline { 2 - 5 } & Sig. (2-tailed) & &, 043 &, 002 \\
\cline { 2 - 5 } & $\mathrm{N}$ & 12 & 12 & 12 \\
\hline \multirow{4}{*}{ BVPS } & Pearson Correlation &, $592^{*}$ & 1 &, $629^{*}$ \\
\cline { 2 - 5 } & Sig. (2-tailed) &, 043 & &, 028 \\
\cline { 2 - 5 } & $\mathrm{N}$ & 12 & 12 & 12 \\
\hline \multirow{3}{*}{ HS } & Pearson Correlation &, $799^{* *}$ &, $629^{*}$ & 1 \\
\cline { 2 - 5 } & Sig. (2-tailed) &, 002 &, 028 & 12 \\
\cline { 2 - 6 } & $\mathrm{N}$ & 12 & 12 & \\
\hline
\end{tabular}

*. Correlation is significant at the 0.05 level (2-tailed).

**. Correlation is significant at the 0.01 level (2-tailed).

Sumber : Data diolah SPSS V.20, 2018

Tabel 4.10 di atas, meberi informasi bahwa antara $\operatorname{EPS}\left(\mathrm{X}_{1}\right)$ dengan BVPS $\left(\mathrm{X}_{2}\right)$, koefisien korelasi ( $\mathrm{r}$ ) sebesar 0,592 dengan tingkat signifikasi 0,043 . Hal ini berarti ada korelasi positif antara EPS dengan BVPS dengan tingkat hubungan sedang. Dapat dilihat juga bahwa antara $\operatorname{EPS}\left(\mathrm{X}_{1}\right)$ dengan harga saham(Y) terdapat koefisien korelasi (r) sebesar 0,799 dengan tingkat signifikasi 0,002 . Hal ini berarti bahwa ada korelasi positif antara EPS dengan harga saham dengan tingkat hubungan sangat kuat. Dan antara $\operatorname{BVPS}\left(\mathrm{X}_{2}\right)$ dengan harga saham(Y) terdapat koefisien korelasi (r) sebesar 0,629 dengan tingkat signifikasi 0,028. Hal ini berarti bahwa ada korelasi positif antara BVPS dengan harga saham dengan tingkat hubungan kuat.

4. Koefisien Determinasi $\left(\mathbf{R}^{2}\right)$

Koefisien determinasi $\left(\mathrm{R}^{2}\right)$ pada intinya kemampuan variabel bebas (independent) dalam menjelaskan kontribusi pengaruhnya terhadap variabel terikat (dependen). Oleh karena itu, banyak peneliti yang menganjurkan untuk menggunakan nilai Adjusted $\mathrm{R}^{2}$ pada saat mengevaluasi model regresi yang terbaik (Ghozali; 2013:97) .

\section{Tabel}

Uji Koefisien Determinasi Model Summary ${ }^{b}$

\begin{tabular}{|l|r|r|r|r|}
\hline Model & R & R Square & $\begin{array}{c}\text { Adjusted R } \\
\text { Square }\end{array}$ & $\begin{array}{c}\text { Std. Error of the } \\
\text { Estimate }\end{array}$ \\
\hline 1 &, $823^{\mathrm{a}}$ &, 677 &, 605 & 192,00803 \\
\hline
\end{tabular}

a. Predictors: (Constant), BVPS, EPS

b. Dependent Variable: HS

Sumber : Data Sekunder diolah SPSS V.20, 2018

Berdasarkan tabel 4.11 di atas, dapat dilihat nilai Adjusted $\mathrm{R}^{2}$ adalah sebesar 0,605. Hal ini menunjukkan bahwa pengaruh duavariabel bebas (EPS dan BVPS) terhadap variabel terikat 
(harga saham) sebesar 60,5\% sedangkan 39,5\% dipengaruhi oleh faktor/variabel lain yang tidak dianalisis dalam penelitian ini.

\section{Uji Signifikansi}

\section{a. Uji Parsial (Uji t)}

Uji signifikansi parsial (uji-t) dilakukan untuk memastikan signifikansi pengaruh dari tiap-tiap variabel bebas $\left(\mathrm{X}_{1}\right.$ dan $\mathrm{X}_{2}$ ) terhadap variabel $\mathrm{Y}$.

Hipotesis dalam uji t, yaitu :

1) $\mathrm{H}_{\mathrm{o} 1}$ : Tidak terdapat pengaruh yang signifikan variabel EPS terhadap variabel harga saham pada PT Lippo Karawaci, Tbk.

$\mathrm{H}_{\mathrm{a} 1}$ : Terdapat pengaruh yang signifikan variabel EPS terhadap variabel harga saham pada PT Lippo Karawaci, Tbk.

2) $\mathrm{H}_{\mathrm{o} 2}$ : Tidak terdapat pengaruh yang signifikan variabel BVPS terhadap variabel harga saham pada PT Lippo Karawaci, Tbk.

$\mathrm{H}_{\mathrm{a} 2}$ : Terdapat pengaruh yang signifikan variabel BVPS terhadap variabel harga saham pada PT Lippo Karawaci, Tbk.

Kriteria pengujian dan pengambilan keputusan untuk uji $\mathrm{t}$ (parsial) adalah :

1) Berdasarkan nilai t hitung dan $t$ tabel

a) Jika nilai $\mathbf{t}_{\text {hitung }} \leq \mathbf{t}_{\text {tabel }}$, maka $\mathrm{H}_{\mathrm{o}}$ diterima dan $\mathrm{H}_{\mathrm{a}}$ ditolak.

b) Jika nilai $\mathbf{t}_{\text {hitung }} \geq \mathbf{t}_{\text {tabel }}$, maka $\mathrm{H}_{\mathrm{o}}$ ditolak dan $\mathrm{H}_{\mathrm{a}}$ diterima.

2) Berdasarkan nilai signifikan hasil output SPSS

a) Jika besaran nilai sig. $>0,05$, maka $\mathrm{H}_{\mathrm{o}}$ diterima dan $\mathrm{H}_{\mathrm{a}}$ ditolak.

b) Jika besaran nilai sig. $<0,05$, maka $\mathrm{H}_{\mathrm{o}}$ ditolak dan $\mathrm{H}_{\mathrm{a}}$ diterima

\section{Tabel}

Hasil Pengujian (Uji t)

Coefficients $^{\text {a }}$

\begin{tabular}{|r|r|r|r|r|r|r|}
\hline \multicolumn{2}{|c|}{ Model } & \multicolumn{2}{|c|}{$\begin{array}{c}\text { Unstandardized } \\
\text { Coefficients }\end{array}$} & $\begin{array}{c}\text { Standardized } \\
\text { Coefficients }\end{array}$ & \multirow{2}{*}{ T } & \multirow{2}{*}{ Sig. } \\
\cline { 3 - 7 } \multicolumn{2}{|c|}{} & \multicolumn{1}{|c|}{ B } & Std. Error & \multicolumn{1}{c|}{ Beta } & \\
\hline \multirow{4}{*}{1} & $\begin{array}{c}\text { (Constant } \\
\text { 1 }\end{array}$ & 434,871 & 143,265 & & 3,035 &, 014 \\
\cline { 2 - 7 } & EPS & 5,790 & 2,072 &, 657 & 2,795 &, 021 \\
\cline { 2 - 7 } & BVPS &, 293 &, 286 &, 241 & 1,023 &, 333 \\
\hline
\end{tabular}

a. Dependent Variable: HS

Sumber : Data Sekunder diolah SPSS V.20, 2018

Tabel 4.12 , uji parsial maka didapat kesimpulan :

1) Nilai $t_{\text {hitung }}$ EPS sebesar 2,79500 lebih besar dari nilai

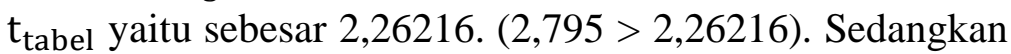

tingkat signifikansi 0,021 lebih kecil dari 0,05 
$(0,021<0,05)$, maka diartikan $\mathrm{H}_{\mathrm{o} 1}$ ditolak dan $\mathrm{H}_{\mathrm{a} 1}$ diterima sehingga dapat disimpulkan bahwa secara parsial Earning Per Share (EPS) berpengaruh signifikan terhadap harga saham.

2) Nilai $t_{\text {hitung }}$ variabel BVPS adalah 1,023 lebih kecil dari nilai $t_{\text {tabel }}$ yaitu sebesar 2,26216. Sedangkan tingkat signifikansi 0,333 lebih besar dari 0,05 ,maka dapat ditarik kesimpulan bahwa $\mathrm{H}_{\mathrm{o} 2}$ diterima dan $\mathrm{H}_{\mathrm{a} 2}$ ditolak, yang berarti secara parsial Book Value Per Share (BVPS) berpengaruh tidak signifikan terhadap harga saham.

\section{b. Uji Simultan (Uji F)}

1. Hipotesis uji F ini yaitu :

a.) $\mathrm{H}_{\mathrm{O} 3}$ : Tidak terdapat pengaruh yang signifikan antara EPS dan BVPS secara simultan terhadap variabel harga saham pada PT Lippo Karawaci, Tbk.

b.) $\mathrm{H}_{\mathrm{a} 3}$ : Terdapat pengaruh yang signifikan antara EPS dan BVPS secara bersama-sama terhadap harga saham pada PT Lippo Karawaci, Tbk.

2. Kriteria pengujian dan pengambilan keputusan :

1) Berdasarkan nilai $F$ hitung dan $F$ tabel

a) Jika $\mathrm{F}_{\text {hitung }} \leq \mathrm{F}_{\text {tabel }}$ maka $\mathrm{H}_{\mathrm{o}}$ diterima dan $\mathrm{H}_{\mathrm{a}}$ ditolak.

b) Jika $\mathrm{F}_{\text {hitung }} \geq \mathrm{F}_{\text {tabel }}$ maka $\mathrm{H}_{\mathrm{o}}$ ditolak dan $\mathrm{H}_{\mathrm{a}}$ diterima.

2) Berdasarkan nilai signifikan hasil output SPSS

a) Jika nilai sig. $>0,05$ maka $\mathrm{H}_{\mathrm{o}}$ diterima dan $\mathrm{H}_{\mathrm{a}}$ ditolak.

b) Jika nilai sig. $<0,05$ maka $\mathrm{H}_{\mathrm{o}}$ ditolak dan $\mathrm{H}_{\mathrm{a}}$ diterima.

Tabel

Uji Simultan (Uji F)

ANOVA $^{\mathrm{a}}$

\begin{tabular}{|l|l|r|r|c|c|c|}
\hline \multicolumn{2}{|l|}{ Model } & $\begin{array}{c}\text { Sum of } \\
\text { Squares }\end{array}$ & Df & $\begin{array}{c}\text { Mean } \\
\text { Square }\end{array}$ & F & Sig. \\
\hline \multirow{3}{*}{1} & Regression & 694716,239 & 2 & 347358,120 & 9,422 &, $006^{\mathrm{b}}$ \\
\cline { 2 - 7 } & Residual & 331803,761 & 9 & 36867,085 & & \\
\cline { 2 - 7 } & Total & 1026520,000 & 11 & & & \\
\hline
\end{tabular}

a. Predictors: (Constant), BVPS, EPS

b. Dependent Variable: HS

Sumber : Data Sekunder diolah SPSS V.20, 2018

Atas dasar tabel 4.13 hasil uji simultan (uji F) maka dapat dilihat nilai $F_{\text {hitung }}$ lebih besar dari nilai $F_{\text {tabel }}(9,422>$ 4,10). Tingkat signifikasi 0,006 lebih kecil dari 0,05 (0,006 $<0,050$ ), maka $\mathbf{H}_{\mathbf{o} 3}$ ditolak dan $\mathbf{H}_{\mathbf{a} 3}$ diterima, sehingga dapat disimpulkan bahwa secara simultan EPS dan BVPS berpengaruh signifikan terhadap variabel harga saham

\section{PENUTUP}

\section{A. Kesimpulan}

Analisis dan pembahasan serta pembuktian terhadap hipotesis dari permasalahan yang diangkat pada PT Lippo Karawaci, Tbk periode 2005-2012, maka dapat diambil kesimpulan : 
1. Secara parsial variabel independen $\left(\mathrm{X}_{1}\right)$ yaitu EPS berpengaruh signifikan terhadap variabel harga saham, karena memiliki signifikansi $<0,05(0,021<0,05)$ dan nilai $t_{\text {hitung }}>t_{\text {tabel }}(2,795>2,26216)$, berarti EPS dapat digunakan untuk memprediksi harga saham $(\mathrm{t}+1)$ dalam berinvestasi. Hal ini konsisten dengan hasil penelitian Mutaqin Yuniatmoko (2013) dan Yunita Laras Sari (2017).

2. Secara parsial variabel independen $\left(\mathrm{X}_{2}\right)$ yaitu BVPS tidak berpengaruh signifikan terhadap variabel harga saham, karena memiliki signifikansi $>0,05(0,333>0,05)$ dan nilai $t_{\text {hitung }}<t_{\text {tabel }}(1,023<2,26216)$. Hal ini berarti BVPS tidak dapat digunakan untuk memprediksi harga saham, ternyata bertentangan dengan hasil penelitian Mutaqin Yuniatmoko (2013) dan Yunita Laras Sari (2017).

3. Secara simultan variabel EPS dan BVPS berpengaruh signifikan terhadap variabel harga saham, karena memiliki signifikansi $<0,05$ $(0,006<0,05)$ dan nilai $F_{\text {hitung }}>F_{\text {tabel }}(9,422>4,10)$. Hal ini berarti EPS dan BVPS dapat digunakan sebagai alat untuk memprediksi perubahan harga saham ke depan, konsisten dengan hasil penelitian Mutaqin Yuniatmoko (2013) dan Yunita Laras Sari (2017).

\section{B. Keterbatasan}

Beberapa keterbatasan adalah :

1. Dalam hal memilih dan menentukan jumlah variabel yang diteliti, yang hanya diwakili oleh dua variabel bebas yaitu EPS dan BVPS.

2. Masih terdapat banyak variabel lain yang memiliki pengaruh terhadap harga saham PT Lippo Karawaci, Tbk yang tidak diteliti.. Terbukti dan dapat diketahui dari nilai Adjusted $\mathrm{R}^{2}$ adalah sebesar 0,605 atau 60,5\% sedangkan sisanya 39,5\% dipengaruhi oleh variabel lain yang tidak diuji dalam penelitian ini.

\section{Saran}

Beberapa saran yang dapat diampaikan :

1. Investor dapat mempertimbangkan untuk faktor lain, karena kedua variabel independent yang diteliti tidak cukup signifikan perlu dicoba analisis variabel lain yang berhubungan dan terkait seperti ROA, ROE, PBV, kondisi ekonomi dan bahkan nilai tukar rupiah.

2. Bagi perusahaan PT Lippo Karawaci, Tbk diharapkan lebih memperhatikan kemampuan perusahaan dalam meningkatkan EPS, karena semakin tinggi nilainya berarti devidennya akan lebih besar, dan pada akhirnya harga saham juga akan meningkat..

3. Bagi peneliti selanjutnya disarankan untuk menambahkan variabelvariabel lain yang diduga memiliki pengaruh yang lebih kuat misalnya Return On Assets, Return On Equity, dan Price Book Value serta menambah periode dan menggunakan teknik analisis lain selain yang digunakan dalam penelitian ini.

\section{DAFTAR PUSTAKA}

Agus, R. Sartono. 2010. Manajemen Keuangan Teori dan Aplikasi. Edisi Keempat. Yogyakarta: BPFE

Appley A, Lawrence dan Lee, Oey Liang. 2010. Pengantar Manajemen. Jakarta: Salemba Empat 
Brigham dan Houston. 2010. Dasar-dasar Manajemen Keuangan Buku 1. Edisi 11. Jakarta: Salemba Empat

Fahmi, Irham. 2012. Analisis Laporan Keuangan. Edisi Pertama. Bandung: Alfabeta

Gumanti, Tatang. 2011. Manajemen Investasi : Konsep, Teori, dan Aplikasi. Edisi Pertama. Jakarta: Mitra Wacana Media

Ghozali, Imam. 2013. Aplikasi Analisis Multivariate dengan Program SPSS. Edisi Ketujuh. Semarang: Badan Penerbit Universitas Diponegoro

Sugiyono. 2014. Metode Penelitian Kuantitatif, Kualitatif, dan Kombinasi (Mixed Methods). Bandung : Alfabeta

Tryfino. 2009. Cara Cerdas Berinvestasi Saham. Edisi Pertama. Jakarta : Transmedia Pustaka

Weston, J. Fred, dan F. Brigham Eugene yang dialih bahasakan oleh Alfonsus Sirait, S.E., M.Bus. 2009. Dasar-dasar Manajemen Keuangan. Jakarta: Erlangga

\section{WEBSITE}

www.duniainvestasi.com

www.finansialku.com

www.idnfinancials.com

www.idx.co.id 